\title{
Effects of floor space area in battery cages on the bird weight and egg production of olympia black layers
}

\author{
K.A. Iyalabani ${ }^{1}$, O.O. Oniya ${ }^{1}$, J.A. Osunade ${ }^{2}$ and J.A. Olaniran ${ }^{1}$ \\ 1 Engineering Faculty, Department of Agricultural Engineering, Ladoke Akintola University of \\ Technology, P.M.B 4000 Ogbomoso, Oyo State Nigeria \\ 2 Obafemi Awolowo University Ile-Ife Osun State Nigeria
}

\begin{abstract}
The impact of varying floor space area in battery cages have been evaluated on the weight and egg production of olympia black laying birds. The experiment was carried out using battery cages with varying floor spaces area of $300 \mathrm{~mm}$ by $300 \mathrm{~mm}, 380 \mathrm{~mm}$ by $380 \mathrm{~mm}$ and $460 \mathrm{~mm}$ by $460 \mathrm{~mm}$ also stocked with 2 and 3 birds per cage cell. The experimental birds used were 45 Olympia black layers, which are seventeen weeks old and the experiment lasted for twelve weeks. The birds' weights were measured while egg production was determined on weekly bases. Design expert software 6.0.8 version was used for experimental design and analysis of the experiment. The results obtained shows that Cage cells $380 \mathrm{~mm} \times 380 \mathrm{~mm}$ with 2 birds gave the optimum weight of birds to be $1.46 \mathrm{~kg}$ and also gave the optimum egg production of 7 eggs per bird per week while cage cells (300 $\mathrm{mm} \times 300 \mathrm{~mm}$ ) with 3 birds gave the lowest productivity with egg production 4 eggs per bird per week. There was a significant effect of stocking density on the weight of bird and egg production at $\mathrm{P}<0.05$. The study was able to established a template for the development of battery cage, which caters for maximum productivity and welfare of laying birds
\end{abstract}

Keywords: Stocking density, battery cages and egg production.

DOI: $10.7176 /$ ISDE/10-7-05

Publication date: September 30th 2019

\section{Introduction}

Poultry production methods involving large number of birds living in a controlled environment under the supervision of a farmer; the houses are expected to provide everything the birds need to maintain their welfare and performance. Generally, environmental factors such as temperature and humidity have high effect on livestock production(Baxter, 1994). However, poultry production highly depends on the temperature and humidity of their immediate environment. The significance of stocking density in poultry performance was established at the beginning of the development of industrial poultry production (Škrbić et at., 2009). In the design of livestock housing, an adequate floor space area is a good requirement for optimum production. This is to ensure good ventilation, high productivity and maximum profit accuracy of the business. Poultry welfare has been regarded as a controversial topic in modern animal agriculture because of the discrepancy of opinions regarding how animals should be treated and maintained (Iyalabani, 2015). There are numbers of minimum standard of stocking density employed in temperate regions (NAWAC, 2012), Duncan (2004) reported that commercial battery cages stocking densities decreases the welfare of the birds which has negative impact on the productivity of the birds, while too much floor space area is un-economical. In temperate countries an important effect of poultry welfare legislation was to reduce stocking density (Elson and Tauson, 2011). In the design of livestock housing, adequate floor space area is a good requirement for healthy and optimum production of poultry farms. This is to ensure good ventilation, high productivity and hence, maximum profit of the business. Traditional battery cage are not sufficiently high enough to provide allowance for the hen, which means that hens are crowded together. Zehra et al., (2006) found out that cage height, width and feeder space affect productive performance of layers. Factors such as feeding rate, types of feed and so on, account for variation in the number of eggs produced per bird per day (Zehra et al., 2006). Duncan (2004) also reported that commercial battery cage densities used in the North America $\left(300-350 \mathrm{~cm}^{2}\right.$ per bird in the United States and $450 \mathrm{~cm}^{2}$ in Canada) decreased the welfare of the birds. In developed countries an important effect of poultry welfare legislation was to reduce stocking density (Elson and Tauson, 2011). However many researches have been carried out on hen stocking density in temperate region but very few in South-South, Nigeria. Hence there are no enough data on stocking density of birds in Southwestern Nigeria. The stocking density employed by poultry farmers and indeed by the cage manufacturers are the standard from temperate countries. It is therefore necessary for researchers in the tropical region of the world (particularly Nigeria) to carry out experiments with a view to investigate the stocking density that will be relevant to determine and establish a minimum standard that can be adopted and serve as template for development of battery cages in our own environment. It is in this view, that this study focused on the effects of floor space area in battery cages on bird weight and egg production of olympia black layers 


\section{Materials and Method}

The study work evaluates the effects of floor space area in battery cages on bird weight and egg production of olympia black layers. The experiment lasted for twelve weeks between January and April, 2014, the climatic condition of the study site falls into the late dry season and early raining season, the experiment was carried out in Ogbomoso, Oyo State located in South-West geopolitical zone of Nigeria, with characteristic features of a savanna (longitude $8.9^{\circ} \mathrm{N}$ and latitude $4.15^{\circ} \mathrm{E}$ ). The experiment was carried out using battery cages with varying floor spaces area and stocking density. The recommended floor dimensions adopted for the study were $300 \mathrm{~mm} \times 300$ $\mathrm{mm}, 380 \mathrm{~mm} \times 380 \mathrm{~mm}$ and $460 \mathrm{~mm} \times 460 \mathrm{~mm}$ respectively. The choice of these dimensions was based on the responses from a preliminary interview conducted to justify what is obtainable with the local farmers. A constant cage cell of $300 \mathrm{~mm} \times 300 \mathrm{~mm}$ was divided into two rolls making a total of six cells; the first row was stocked with 2 birds per cage cell while the second row was stocked with 3 birds respectively. The reason for the stocking density was based on the local content adopted for rearing of birds in the study area. The same procedure was repeated for $380 \mathrm{~mm} \times 380 \mathrm{~mm}$ and $460 \mathrm{~mm} \times 460 \mathrm{~mm}$ respectively. The total sum of cages constructed for this research work was six, with each cage containing three cells. The cages were placed in an open space which is fenced against predator attack and sheltered with polyvinyl sack to protect the birds from direct sun radiation. The choice of housing is made to provide equal environmental condition to the birds. The experimental animals used were 45 Olympia black layer birds at their $17^{\text {th }}$ week of age; they were introduced to the battery cage as recommended by Midwest Plan Service (1983). The feed given to the birds was purchased from Premier Feed Mills Co. LTD. RC 791117. The composition of feed and metabolized energy of the feed is given in Table1. The choice of feed was based on recommendation from local poultry farmers and Awoniyi (2003). Measurement of weight of birds and weight gained was done using a measuring scale with ranges between $0-20 \mathrm{~kg}$ and sensitivity of $( \pm 0.1)$. The initial weight of the birds was taking while subsequent weight was taking on weekly basis for the whole time of the research while the egg production were determined on weekly basis. The design layout for the study was two numerical factor which was Floor space ( three levels) and Stoking density (two levels) which was replicated three times as shown in Table 2. Response Surface Methodology (RSM) was adopted for the study using historical data, the total runs of the experiments were 18 and its design model was linear Design expert software 6.0.8 version was used for analysis of the effects of floor space area in battery cages on bird weight and heat production of olympia black layers.

Table 1: Feed Composition

\begin{tabular}{lc}
\hline Ingredient & Mass constituent in $(\mathrm{Kg})$ \\
\hline Crude protein & 16.50 \\
Fats (oil) & 5.00 \\
Calcium & 6.00 \\
Available phosphorus & 3.60 \\
Lysine & 0.45 \\
Methionine & 0.80 \\
Kcal/Kg Metabolized Energy & 2500 \\
\hline
\end{tabular}


Table 2: Design Layout

\begin{tabular}{|c|c|c|c|c|c|c|}
\hline & \multicolumn{3}{|c|}{2 Birds $\left(L_{1}\right.$} & \multicolumn{3}{|c|}{3 Birds $\left(L_{2}\right)$} \\
\hline $\begin{array}{l}300 \times 300 \\
\mathrm{~mm}\left(\mathrm{~S}_{1}\right)\end{array}$ & $\mathrm{S}_{1} \mathrm{~L}_{1}$ & $\mathrm{~S}_{1} \mathrm{~L}_{1}$ & $\mathrm{~S}_{1} \mathrm{~L}_{1}$ & $\mathrm{~S}_{1} \mathrm{~L}_{2}$ & $\mathrm{~S}_{1} \mathrm{~L}_{2}$ & $\mathrm{~S}_{1} \mathrm{~L}_{2}$ \\
\hline $\begin{array}{l}380 \times 380 \\
\mathrm{~mm}\left(\mathrm{~S}_{2}\right)\end{array}$ & $\mathrm{S}_{2} \mathrm{~L}_{1}$ & $\mathrm{~S}_{2} \mathrm{~L}_{1}$ & $\mathrm{~S}_{2} \mathrm{~L}_{1}$ & $\mathrm{~S}_{2} \mathrm{~L}_{2}$ & $\mathrm{~S}_{2} \mathrm{~L}_{2}$ & $\mathrm{~S}_{2} \mathrm{~L}_{2}$ \\
\hline $\begin{array}{c}460 \times 460 \\
\mathrm{~mm}\left(\mathrm{~S}_{3}\right)\end{array}$ & $\mathrm{S}_{3} \mathrm{~L}_{1}$ & $\mathrm{~S}_{3} \mathrm{~L}_{1}$ & $\mathrm{~S}_{3} \mathrm{~L}_{1}$ & $\mathrm{~S}_{3} \mathrm{~L}_{2}$ & $\mathrm{~S}_{3} \mathrm{~L}_{2}$ & $\mathrm{~S}_{3} \mathrm{~L}_{3}$ \\
\hline
\end{tabular}

\section{Results and discussion}

\subsection{Effect of floor space on weight of birds}

Table 3 shows the weight of birds taken for twelve weeks from which the average weight of birds showed that the cage cell stocked with two birds gained more weight than others in the last weeks of the study which is between $8^{\text {th }}$ and $12^{\text {th }}$ weeks. The cage cell $460 \mathrm{~mm} \times 460 \mathrm{~mm}$ with two stocking density gained an average weight of $1.48 \mathrm{~kg}$ and $1.46 \mathrm{~kg}$ at the end of $8^{\text {th }}$ and $12^{\text {th }}$ weeks respectively, which was the highest weight gained. At the end of $8^{\text {th }}$ and $12^{\text {th }}$ weeks, cage cell $380 \mathrm{~mm} \times 380 \mathrm{~mm}$ stocked with two birds gained $1.46 \mathrm{~kg}$ and $1.42 \mathrm{~kg}$ weight respectively, which came close comparing it with highest weight gained. It showed that the weight gained by these birds over the weeks of the study is dependent on the floor space area of the cage cell. Taking a look at the cage cell $300 \mathrm{~mm} \times 300 \mathrm{~mm}$ stocked with 3 birds, weight gained by birds at the $12^{\text {th }}$ was $1.41 \mathrm{~kg}$ and this weight gained is higher compared to others of the same floor space area with 2 stocking density. The tabulated results indicated that the cage floor space area has effects on the weight of birds. Also there is fluctuation in the weight of the birds' week in, week out, when the birds start dropping eggs. Table 4 indicated that floor space area is significant. The Model F-value of 898.14 implies the model is significant, $\mathrm{R}^{2}$ is given as 0.9948 while the "Pred $\mathrm{R}^{2}$ " of 0.9905

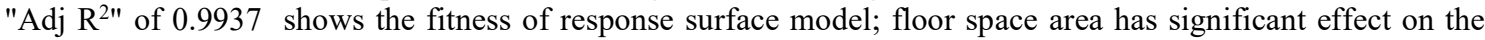
weight of the birds $(\mathrm{p}<0.0500)$. Figure 1 is the shape of three dimensional surface response plot it shows the material balance between the response which is the weight of birds in $\mathrm{kg}$ and the two factors which are floor space area and stocking density. The maximum wieght of birds $15.56 \mathrm{~kg}$ were obtained at the highest floor space area of $460 \mathrm{~mm} \times 460 \mathrm{~mm}$ and the lowest $14.21 \mathrm{~kg}$ also obtained at $300 \mathrm{~mm} \times 300 \mathrm{~mm}$ which was the lowest floor space area, while cage cell stocked with three birds gained less weight of $14.21 \mathrm{~kg}$. 
Table: 3 Summary of average weight of birds on four weeks interval

\begin{tabular}{|c|c|c|c|}
\hline Cage cell & $\begin{array}{l}\text { From day one to } 4 \text { th } \\
\text { week }(\mathrm{kg})\end{array}$ & $\begin{array}{l}\text { From } 4 \text { th week to } 8 \text { th } \\
\text { week }(\mathrm{kg})\end{array}$ & $\begin{array}{l}\text { From } 8 \text { th week to } 12 \text { th } \\
\text { week }(\mathrm{kg})\end{array}$ \\
\hline A1L1 & 0.96 & 1.25 & 1.29 \\
\hline A2L1 & 1.21 & 1.44 & 1.38 \\
\hline A3L1 & 1.14 & 1.37 & 1.30 \\
\hline B1L2 & 1.2 & 1.48 & 1.46 \\
\hline B2L2 & 1.09 & 1.3 & 1.21 \\
\hline B3L2 & 1.08 & 1.32 & 1.36 \\
\hline C1L1 & 1.02 & 1.28 & 1.34 \\
\hline C2L1 & 0.98 & 1.3 & 1.34 \\
\hline C3L1 & 1.11 & 1.45 & 1.35 \\
\hline D1L2 & 1.1 & 1.26 & 1.31 \\
\hline D2L2 & 1.16 & 1.46 & 1.42 \\
\hline D3L2 & 1.1 & 1.38 & 1.37 \\
\hline E1L1 & 0.94 & 1.21 & 1.16 \\
\hline E2L1 & 0.94 & 1.21 & 1.16 \\
\hline E3L1 & 1.08 & 1.36 & 1.41 \\
\hline F1L2 & 1.08 & 1.16 & 1.25 \\
\hline F2L2 & 1.14 & 1.34 & 1.3 \\
\hline F3L2 & 1.14 & 1.29 & 1.29 \\
\hline $\begin{array}{l}A=460 n \\
B=460 m \\
C=380 n \\
D=380 m\end{array}$ & $\begin{array}{l}\text { a by } 460 \mathrm{~mm} \\
\text { by } 460 \mathrm{~mm} \\
\text { by } 380 \mathrm{~m} \\
\text { by } 380 \mathrm{~mm}\end{array}$ & $\begin{array}{l}\mathrm{E}=300 \mathrm{~mm} \\
\mathrm{~F}=300 \mathrm{~mm} \mathrm{~b} \\
\mathrm{~L}_{1}=3 \mathrm{birds} \\
\mathrm{L}_{2}=2 \mathrm{birds}\end{array}$ & $\mathrm{mm}$ \\
\hline
\end{tabular}

Table 4: ANOVA Analysis of the effect of floor space area on bird weight

\begin{tabular}{|c|c|c|c|c|c|}
\hline Source & $\begin{array}{l}\text { Sum of } \\
\text { Squares }\end{array}$ & DF & Mean Squares & F-Value & Prob $>F$ \\
\hline Model & 3.39 & 3 & 1.13 & 898.14 & $\begin{array}{l}<0.0001 \\
\text { significant }\end{array}$ \\
\hline A & 2.62 & 1 & 2.62 & 2085.56 & $\begin{array}{l}<0.0001 \\
\text { significant }\end{array}$ \\
\hline B & 0.76 & 1 & 0.76 & 608.07 & $\begin{array}{l}<0.0001 \\
\text { significant }\end{array}$ \\
\hline Residual & 0.018 & 14 & $1.258 \mathrm{E}-003$ & & \\
\hline Lack of Fit & $3.472 \mathrm{E}-003$ & 2 & $1.736 \mathrm{E}-003$ & 1.47 & $\begin{array}{l}0.2677 \text { not } \\
\text { significant }\end{array}$ \\
\hline Pure Error & 0.014 & 12 & $1.178 \mathrm{E}-003$ & & \\
\hline Cor Total & 3.41 & 17 & & & \\
\hline
\end{tabular}




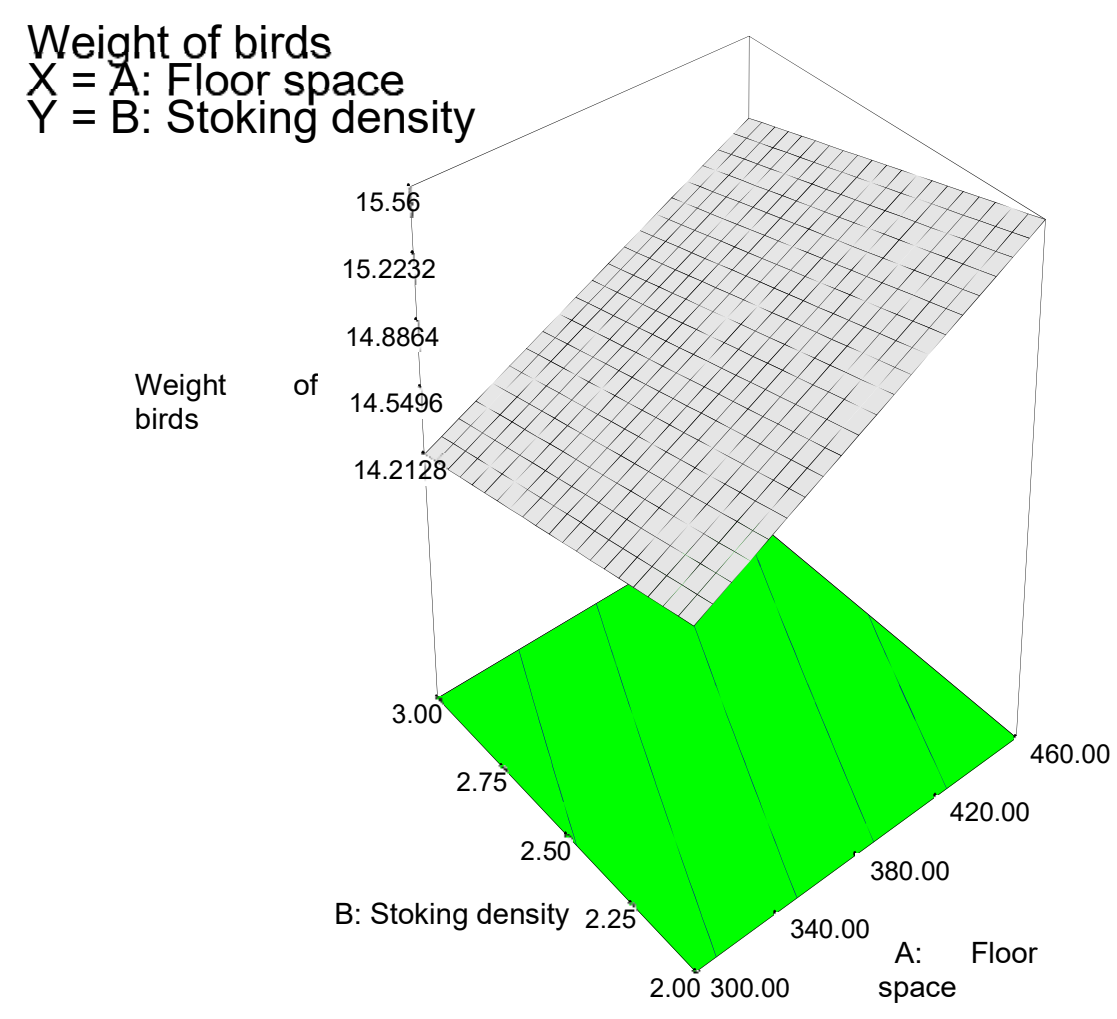

Figure 2: Response Surface Plot of Weight of Birds as Function of Stocking Density and Floor Space Area

The intercept between the two factors is $14.88 \mathrm{~kg}$; this plot can be use to navigate the design of floor space area against the stocking density. This result is in line with the result obtained by Sarica et al. (2008) who observed that live weight of birds were moderately higher in hens allowed more space compared to those kept at lower space allowances; and also the high live weight of birds could be explained by higher feed comsumption and water intake during the experiment period. Onbasilar and Aksoy (2005) also found out that increased stocking density by increasing the number of hens per cage from 1 to 5, decreases the live weight of HY-Line Brown genotype. However Jalal et al. (2006) find significant effect of space allowance on the weight of hens in cages having $690 \mathrm{~cm}^{2}, 516 \mathrm{~cm}^{2}, 413 \mathrm{~cm}^{2}$ and $372 \mathrm{~cm}^{2}$ per hen.

\subsection{Effect of floor space area on egg production}

The effect of floor space area on egg production was illustrated in table 5. Table 5 is a Summary of average egg production per bird on Four weeks interval an average four weeks, egg layed by the birds in the cell cage at the first four weeks of introduction to the battery cage cell only birds with two stocking density starts production. This result clearly showed that stocking density is a key player in productivity of a laying hen. This result shows that irrespective of the cage floor space the birds that are stocked two are the once that begin to lay at the fourth week of introduction to cage. At the last four weeks making it twelveth week, the performance of the birds in the cage cell shows that the best performance was obtained from cage cells with two stocking density the best of all is cage cell $380 \times 380 \mathrm{~mm}$ with an average number of 7 eggs per bird per week in the cage cell. The lowest record was 4 eggs per cage cell per week and it is common among cage cells with 3 stocking density. This implies that the egg production is affected by the increase in stocking density irrespective of the floor spaace area. 
Table 5: Summary of Average Hen-House Egg Production Per Bird Per Four weeks

\begin{tabular}{lccc}
\hline $\begin{array}{l}\text { Cell } \\
\text { cage }\end{array}$ & $\begin{array}{l}\text { From day one to } \\
4^{\text {th }} \text { week }\end{array}$ & $\begin{array}{l}\text { From } 4^{\text {th }} \text { week to } \\
8^{\text {th }} \text { week }\end{array}$ & $\begin{array}{c}\text { From } 8^{\text {th }} \text { week to } \\
12^{\text {th }} \text { week }\end{array}$ \\
\hline A1L1 & 0 & 12 & 16 \\
A2L1 & 0 & 20 & 20 \\
A3L1 & 0 & 12 & 16 \\
B1L2 & 2 & 20 & 24 \\
B2L2 & 1 & 12 & 20 \\
B3L2 & 0 & 20 & 16 \\
C1L1 & 0 & 8 & 12 \\
C2L1 & 0 & 8 & 20 \\
C3L1 & 0 & 8 & 24 \\
D1L2 & 2 & 24 & 28 \\
D2L2 & 1 & 16 & 24 \\
D3L2 & 0 & 16 & 24 \\
E1L1 & 0 & 12 & 16 \\
E2L1 & 0 & 12 & 16 \\
E3L1 & 0 & 4 & 24 \\
F1L2 & 2 & 12 & 20 \\
F2L2 & 0 & 12 & 16 \\
F3L2 & 2 & 24 & 24 \\
\hline
\end{tabular}

$\mathrm{A}=460 \mathrm{~mm}$ by $460 \mathrm{~mm}$

$\mathrm{E}=300 \mathrm{~mm}$ by $300 \mathrm{~mm}$

$\mathrm{B}=460 \mathrm{~mm}$ by $460 \mathrm{~mm}$

$\mathrm{F}=300 \mathrm{~mm}$ by $300 \mathrm{~mm}$

$\mathrm{C}=380 \mathrm{~mm}$ by $380 \mathrm{~mm}$

$\mathrm{L} 1=3$ Birds

$\mathrm{D}=380 \mathrm{~mm}$ by $380 \mathrm{~mm}$

$\mathrm{L} 2=2$ Birds

Table 6 showed that only stocking density is significant on the experiment, that is the hen day production is only affected significantly at $\mathrm{P} \leq 0.05$. while the floor space area has no significant effect on the egg production at $\mathrm{P} \geq 0.05$. Figure 1 is a $3 \mathrm{D}$ surface response graph showing that there was decrease in hen week production has the stocking density increases and on the other hand the egg production remain contant as the floor space increases. The best performance was obtained at stocking density of two. During the present study, hen house egg production increase with decrease in the cage stocking density for Olympia black layers. Cage stocked with two birds has higher egg production compared to cage stocked with three birds in the cage been experimented. This result is in line with the expectation that cage related stress and density related social stress would be more in densely populated cages and less in cages sparsely populated (Baxter, 1994). The reason for this is that immediately before laying is stimulated there is high flock uniformity within the birds in high density cages as they compete for both feed and water compared to sparsely populated cages (Zehra et al., 2006). Decrease egg production was shown to be attributable to the reduced feeding area per bird, cannibalism (Nicol et al., 2006; Adams and Craig, 1985). Anderson et al., (2004) found out that high cage stocking density from HY- line W36 and Dekalb XL commercial layer genotypes decreased hen egg production. They reported a decrease in egg production from $82.3 \%$ to $77.4 \%$ because of increase in the cage stocking density from $482 \mathrm{~cm}^{2}$ to $361 \mathrm{~cm}^{2}$ per hen. Onbasilar and Aksoy (2005) determined hen day egg production as $94.1 \%, 89.3 \%$ and $78.5 \%$ at the respective stocking density 1968,656 and $393.8 \mathrm{~cm}^{2}$ per hen with statistical significance $(\mathrm{p}<0.050)$. 
Table 6:Anova Analysis of the Effect of floor space area and Stocking Density on the Hen House Egg Production

\begin{tabular}{llllll}
\hline Source & $\begin{array}{l}\text { Sum of } \\
\text { Squares }\end{array}$ & DF & $\begin{array}{l}\text { Mean } \\
\text { Square }\end{array}$ & F-Value & Prob $>$ F \\
\hline Model & 720.97 & 2 & 360.49 & 6.16 & 0.0112 significant \\
A & 24.08 & 1 & 24.08 & 0.41 & 0.5309 \\
B & 696.89 & 1 & 696.89 & 11.90 & 0.0036 \\
AB & 14.08 & 1 & 14.08 & 0.23 & 0.6402 \\
Residual & 878.14 & 15 & 58.54 & & 0.5861 notsignificant \\
Lack of Fit & 126.14 & 3 & 42.05 & 0.67 & \\
Pure Error & 752.00 & 12 & 62.67 & & \\
Cor Total & 1599.11 & 17 & & \\
Significant at $\mathrm{p}<0.05$, Std. Dev. 7.65, $\mathrm{R}^{2}$ 0.4509, Mean 33.22, Adj R ${ }^{2} 0.3776$, C.V 23.03, Pred R $\mathrm{R}^{2}$ 0.2077, \\
PRESS 1266.93 and Adeq Precision 4.891 A= Floor space area, B = Stocking Density, \\
A = Floor space area, B = Stocking Density,
\end{tabular}

DESIGN-EXPERT Plot

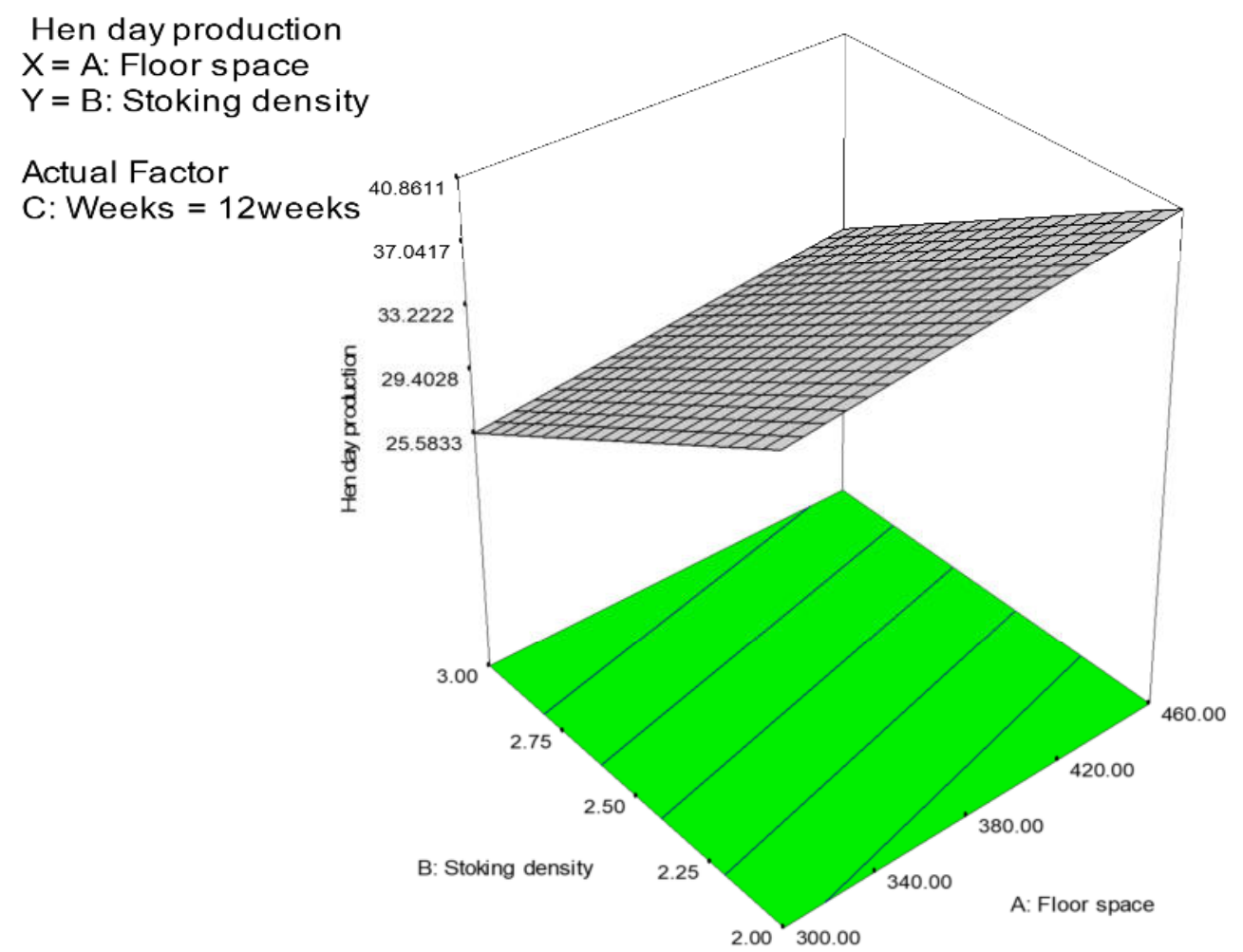

Figure 2: $\quad$ Response Surface Plot of Egg Production as Function of Stocking Density and Floor Space Area

\section{Conclusions}

The floor space area in battery cages has significant effect on the weight of the birds, and the cage cells with the best weight gain, is cage cell with two birds. The best performance on individual cage cell showed that 
cage cell $460 \mathrm{~mm} \times 460 \mathrm{~mm}$ with $1.46 \mathrm{~kg}$ and $380 \mathrm{~mm} \times 380 \mathrm{~mm} 1.42 \mathrm{~kg}$ gained the highest weight within the period of the experiment. Also floor space area in battery cages shows to have significant effect on the bird weight and egg production of the hen. The result obtained shows that only cage cells with two stocking density started egg production earlier and the cage cell with the optimum egg production as cage cell $380 \mathrm{~mm} \times 380 \mathrm{~mm}$ with an average of 7 eggs per bird in the last four weeks, it birds shows consistency in hen day production during the last for weeks of the experiment than others.

\section{References}

Adams, A.W. and Craig, J.V. (1985): Effect of Crowding and Cage Shape on the Productivity and Profitability of Cage Layers. Poultry Science 64, 238-242.

Anderson, K.E., Davis, G.S., Jenkins, P.K. and Carroll, A.S. (2004): Effect of Bird age, Density and Molt on Behavioral Profiles of two Commercial Layer Strains in Cages. Poultry Science, 83, 15-23.

Awoniyi, T. A. M. (2003): The effect of housing on layer-chicken's productivity in the 3-tier cage. International journal of joultry science, vol 2 (6): 438-441.

Baxter, M. R. (1994): The welfare of laying hen in battery cages. Veterinary record, vol 134:614-619.

Duncan, I. J.H. (1991): The pros and cons of cages. World poultry science journals. Vol 8(4): 567-570.

Elson, A. and Tauson, R. (2011): Furnished cages for laying hens in alternative system for poultry health,. welfare and productivity. Livestock, c. o. r.f. t. w. o. (1978-83): fisheries and food.london ministry of agriculture.

Jala, M.A., Scheideler, S.E. and Marx, D. (2006): Effect of bird cage space and dietary metabolizable energy level on production parameters in laying hens. Poultry Science, vol 85 306-311

Midwest Plan Service, (1983):Structures and environment handbook. Eleventh Edition. ISBN 0-89373-057-2.

National Welfare Advisory Committee NAWAC (2012): Animal welfare (laying hen) code of welfare report.

Nicol, C.J., Brown, S.N., Glen, E., Pope, S.J., Short, F.J., Warriss P.D., Zimmerman, P.H. and Wilkins, L.J. (2006): Effects of stocking density flock size and management on the welfare of laying hens in single- tier aviaries. British poultry science, 47, 135-146. poultry health

Onbasilar, E.E. and Aksoy, F.T. (2005): Stress paraameters and immune response of layers underdifferent cage floor and density conditions. Livestock Production Science. Vol (95), page 255-263.

Sarica, M., Boga, S. and Yamak, U.S. (2008): The efects of space allowance on egg yield, egg quality and plumage condition of laying hens in battery cages. Czech J. Anim. Sci., 53, vol 8: 346353.

Škrbić, Z., Pavlovski, Z., Lukić, M. (2009): Stocking Density - Factor of production performance, quality and broilers welfare. Biotechnology in Animal husbandry, vol 25 (5-6): 359-372.

Zehra, B., Smail, B., Smail, T. L., \& Orhan, C. A. (2006): Effects of Cage Density and Cage Position on Performance of Commercial Layer Pullets from Four Genotypes. Turk J Vet Anim Sci, 30, 17-28. 